\title{
JÁRVÁNYOK ÉS DÖGVÉSZ AZ ÓKORI MEZOPOTÁMIÁBAN
}

\author{
BÁCSKAY ANDRÁS
}

\begin{abstract}
Plague and pestilence in ancient Mesopotamia

Cuneiform texts from the second and first millennium are one of the oldest sources for plague or pestilence in the ancient times. Letters from the royal archive of the kingdom Mari written in the early second millennium inform us individual cases of contaminations in royal court and the outbreak of plague in various cities. Similarly to the conception of diseases, plague and pestilence were considered as a punishment of the gods. Moreover, the concept about illnesses including plague is closely connected to the impurity. The Mesopotamians used several medical and magical practices to protect themselves. In this paper magical amulets (so called 'plague amulet' and necklace made of various amulet stones) and a healing treatment (an ointment) were presented. Rituals were also performed to protect domestic animals against pestilence. A complex Neo-Assyrian ritual for purifying the military camp were here also presented.
\end{abstract}

\section{BEVEZETÉS}

Az embereket sújtó járványos megbetegedések, valamint az állatokat megtizedelő dögvész a mezopotámiai emberek hétköznapjaihoz tartoztak. ${ }^{1} \mathrm{Az}$ óbabiloni kori Mári királyi palotájából származó levelek arról tájékoztatnak, hogy egyes betegségek fertőző jellegével is tisztában voltak, így például az egyik levél világosan utal arra, hogy a járvány az egyik városból terjedt át egy másik városra: „Most járvány van a városban. A járvány (azonban) nem Nergal istentől jön, (hanem) Asaru városból.” Egy másik levélben arról olvashatunk, hogy a levél írója sietve haladt át

\footnotetext{
1 A fertőzésekhez és a járványos megbetegedésekhez az ókori Mezopotámiaban lásd Durand 1988: 544-549, Farber 2004; Geller 2010: 68-70 és Huber 2005: 23-48.

${ }^{2}$ Frankena 1966: 118. Attinger 2008: 64.
} 
a járvány által sújtott térségen, illetve javasolja a királynak, hogy tiltsa meg a járvány által érintett települések lakónak a belépését betegséggel még nem fertőződött településekre, beleértve a kereskedelmi karavánokat is. ${ }^{3}$ Ez utóbbi forrás talán a történelem első ismert karantén intézkedését jelenti. ${ }^{4}$ Ugyancsak a fertőzéstől való félelem állhat az alábbi levél mögött is: „Hallottam, hogy Nana simmu betegségben szenved. Bár nem fordul meg gyakran a palotában, mégis sok asszonnyal érintkezik, (ezért) úgy rendelkezem, hogy senki sem ihat abból a kupából, amiből ő ivott (korábban), senki nem ülhet arra a székre, amelyen ő ült (korábban), senki sem fekhet abba az ágyba, amiben ő feküdt (korábban). Nem kerülhet kapcsolatba más asszonnyal. A betegsége fertőző." 5 A kor embere számára megmagyarázhatatlan módon keletkező és terjedő fertőző betegségeket bizonyos istenek és egyes démonok pusztításának tulajdonították, a Máriból származó levelekben a járványra „az isten felfalása” (ukulti ilim) vagy „az isten érintése” (lapat ilim) kifejezésekkel utalnak, illetve a konkrét személyek kötődő fertőzéses betegség kapcsán általában a simmu betegséget vagy az általánosságban betegséget jelentő (murșu) terminusokat említik. ${ }^{6}$ E levelekből világos, hogy Máriban tisztában voltak azzal, hogy a beteggel vagy a beteg által használt tárgyakkal való személyes érintkezés során a betegség megfertőzheti a vele érintkezésbe kerülő személyeket is. Bár a megbetegedéstől, illetve a fertőzéstől való félelem részben talán a gyakorlati tapasztalatból fakadhatott, azonban az ókori Mezopotámiában a betegségek szorosan kapcsolódtak az isteni harag, illetve büntetés, valamint a tisztátalanság gondolatához, így a betegek elkülönítésének oka elsősorban a tisztátalansággal való érintkezés elkerülését szolgálta. ${ }^{7} \mathrm{E}$ felfogás szerint a pácienst gyötrő betegség az isteni harag megnyilvánulása, a páciens pedig a betegség idejére tisztátalanná válik, a tisztátalan pácienssel való érintkezés pedig magában hordozza a tisztátalannal való megfertőződés veszélyét. ${ }^{8}$ Az első évezredi Šurpu című bajelhárító ráolvasássorozat alábbi részlete a betegséggel fertőzött személyhez kapcsolódó tárgyakkal kapcsolatos

${ }^{3}$ Durand 1988: 127.

${ }^{4}$ A járvány kitörésének lehetséges okaihoz lásd Durand 1988: 544-549. A késő bronzkori Szíria és Palesztina térségének településein kitört járványokhoz lásd Klengel 1999.

${ }^{5}$ Durand 2000: 345; Farber 2004: 122 és Attinger 2008: 44.

${ }^{6}$ Farber 2004: 119-120. E terminusok a mezopotámiai ómensorozatok apodoziszaiban is szerepelnek. A szöveghelyekhez lásd CAD L 201-202 sub liptu 2b és CAD U 64 sub ukultu 2b mezopotámiai ómensorozatokhoz magyarul lásd Bácskay-Niederreiter 2013: 203-208.

7 A mezopotámiai betegségfelfogáshoz lásd Geller 2010: 14-39. Magyarul Bácskay 2018a: 125142 .

${ }^{8}$ A szakrális tisztaságról az ókori Mezopotámiában lásd Toorn 1985: 27-30; Abusch 1995: 467494; Guichard-Marti 2013. Magyarul Bácskay 2013: 1-3. 
érintkezési tilalmakat sorol fel. ${ }^{9}$ A forrásrészletben az ártó mágia egyik eljárásának tekinthető átokkal sújtott személlyel, illetve az e személyhez kapcsolódó személyes tárgyakkal való érintkezést jelöli meg a tisztátalanná válás okaként. ${ }^{10}$

(aki) az átokkal sújtott (ember) felé ment,

(aki) felé az átokkal sújtott (ember) ment,

(aki) az átokkal sújtott (ember) ágyába aludt,

(aki) az átokkal sújtott (ember) székében ült,

(aki) az átokkal sújtott (ember) asztalánál evett,

(aki) az átokkal sújtott (ember) poharából ivott.

A ráolvasássorozatban felsorolt tisztátalansági okok összecsengenek e fentebb idézett Máriból származó levélben szereplő szempontokkal, így a fertőzés, illetve a járványos betegségek Mezopotámiában nem annyira orvosi, hanem sokkal inkább vallási-mágikus jelentéstartalommal bírt. A továbbiakban áttekintem a járványos betegségekre vonatkozó fontosabb mezopotámiai terminusokat, valamint a járványos betegségek okozójaként számon tartott isteneket és démonokat, majd e betegségek elhárítására irányuló mágikus-orvosi eljárásokat mutatok be.

\section{TERMINUSOK A JÁRVÁNYOKRA}

A járványos megbetegedésre utaló legáltalánosabb kifejezés az „elhalálozás” jelentésủ akkád mūtānu (sumer nam-ušs), amely a halottat jelentő akkád mūtu (sumer ušs ${ }_{2}$ ) szó származéka. E betegséget forrásaink nem kapcsolják meghatározott szimptómákhoz, azonban a betegségnév és a halott közti szemantikai kapcsolat vélhetően a járványos megbetegedésekkel együtt járó magas halálozási rátán alapult. A gyors terjedés, a nagyszámú halálozás és a hirtelen eltűnés okán e betegséget a kutatás a pestis valamely formájával azonosítja. ${ }^{11}$ Forrásainkban a mūtā$n u$ terminus gyakran együtt szerepel két további betegségnévvel: a heves lázzal

\footnotetext{
${ }^{9} \mathrm{Az}$ 1. évezredi kétnyelvü (sumer-akkád) kanonikus Šurpĥ (jelentése: égetés) ráolvasássorozat kilenc táblából áll, a sorozatot a 2. évezred második felében szerkesztették, a táblák zöme az késői újasszír és a késő babiloni korból (7-4. század) származik. A szöveg első nyolc táblája nagyrészt ráolvasásokat, fohászokat és kapcsolódó rituálé leírását tartalmaz, a 9. tábla pedig a rituális eszközök megtisztítása során recitálandó ráolvasásokat foglal magában. A ráolvasássorozat a szakrális vétségek és vallási-rituális tabuk áthágásának listaszerű felsorolását tartalmazza. A sorozat feldolgozásához lásd Reiner 1970.

${ }^{10}$ Šurpu 2. tábla 98-103. sorok. A sorok magyar fordításához lásd Bácskay 2014: 35.

${ }^{11}$ Wiggermann 1999: 220.
} 
és talán fejfájással járó di’u betegség (sumer sag-gig), ${ }^{12}$ valamint a šibṭu betegség. ${ }^{13}$ A fentebb említett betegség elnevezések mellett egyes bőrbetegségek ugyancsak a fertőző betegségek közé számítottak. Az egyelöre nem azonosítható li'bu vagy la'bu betegség ${ }^{14}$, a mári levelek kapcsán korábban már említett simmu betegség ${ }^{15}$ valamint a vélhetően lepraként azonosítható saharšubbû betegség tartozik ide, melyeket forrásaink alkalomszerűen a járványt általában jelölő „elhalálozás” (mūtānu) terminussal együtt említenek. Itt kell megjegyezni, hogy bár az ókori mezopotámiai források számos betegség nevét, illetve tünetleírásait rögzítik, azonban e betegségek taxonómiai rendszerét, illetve a tünetek és a betegség viszonyát, valamint egymással való megfeleltetésük szempontjait csak részben ismerjük. ${ }^{16} \mathrm{~A}$ korabeli tudományos taxonómia a betegségeket, illetve fizikai tüneteket részben bizonyos testrészekhez kapcsolta, ilyen testrésznek számított a fej, a szem, a száj, a fül, a nyak, a végtagok (elsősorban a láb). Másrészt az első évezredben bizonyos tematikus orvosi sorozatok alakultak ki (e sorozatok elsősorban a ninivei Assur-bán-apli féle könyvtár táblagyüjteményből és az assuri Kiszír-Assur könyvtárából származó tábláktól ismertek), melyek a fentebb jelzett testrészek szerinti csoportosítás mellett külön sorozatot szenteltek a légzési problémáknak, a bőrpanaszoknak vagy a szüléssel kapcsolatos „betegségeknek”. Harmadrészt, a betegségeket természetfeletti okozójuk alapján is számon tartották, így a gyógyító eljárások között külön csoportot alkottak a halotti szellemek vagy a különböző démonok (Lamastu, Asakkú stb.) által okozott fizikai szenvedések és betegségek, illetve bizonyos betegségeket meghatározott istenségek (Istár, Szín, Samas stb.) „csapásaként” vagy „érintéseként” tartottak számon. Bár a fentebb említett járványos megbetegedésekkel összefüggésbe hozható kifejezések nem alkottak külön csoportot első évezredi orvosi szövegsorozatokban a ráolvasáspapi hivatás fontosabb tudományos munkáinak címeit felsoroló „Ráolvasópap kézikönyve” című szövegben a járványos betegségeket jelölő terminusok egyazon munka címében jelennek meg:

${ }^{12}$ Az akkád di’u sumer megfelelőjének (sag-gig) szó szerinti jelentése „fejbetegség” (CAD D 166a, c) ezért a szakirodalomban gyakran di’u-fejbetegség terminussal fordítják. A betegség azonosítása kérdéses, a különböző értelmezésekhez lásd Wiggermann 1992: 91 és 41-42, Böck 2007: 109-110, Kinner-Wilson-Finkel 2007: 20-22 és Stol 2007: 15-18.

${ }^{13}$ A terminus értelmezéséhez lásd Wiggermann 1992: 95.

${ }^{14}$ A li’bu magas lázzal járó betegség, amely alkalomszerűen az általánosságban járványt mūtānu kifejezéssel együtt szerepel. A terminushoz lásd Stol 2007: 11-15 és Bácskay 2018b: 5-6.

${ }^{15}$ A kontextustól függően az akkád simmu terminus jelenthet valamilyen bőrbetegséget vagy sebet, illetve általánosságban a testen érzékelhető sérülést. A kifejezéshez lásd Durand 1988: 552-553; Farber 2004: 20-21; Böck 2014: 109-113. A mezopotámiai bőrbetegségekhez magyarul lásd Bácskay-Simkó 2017.

${ }^{16}$ A mezopotámiai orvoslás betegség koncepciójához magyarul lásd Bácskay 2018a: 125-142. 
„A dì u betegség, a šibțu betegség és a mūtānu betegség eltávolításához". ${ }^{17}$ Ugyan e címmel jelzett munka önálló ráolvasássorozatként egyelőre más forrásból nem ismert a szöveg tartalma vélhetően részben megőrződött az e betegségek elhárítása érdekében végzett bajelhárító rituálék, valamint egyes amulettek szövegében. E rituálékat a tanulmány későbbi részében tárgyalom.

\section{JÁRVÁNYT OKOZÓ ISTENEK ÉS DÉMONOK}

Az országra és az egyénre végzetes csapást jelentő járványok elsősorban Erra és Nergal istenhez köthetők. A „hős” vagy a „járvány és a gyilkolás ura” epithetonokat viselő Erra eredetileg a háborúhoz kötődő istenség, aki járványt és éhínséget okozva pusztítja az emberiséget. ${ }^{18}$ Erra alakja a legkidogozottabban a Kr. e. 8. század körül keletkezett Erra és Isum címü narratívában ragadható meg, amelyben az időlegesen a világ feletti uralmat megszerző Erra az embereket és az állatokat egyaránt elpusztító járvánnyal sújtja az országot. ${ }^{19} \mathrm{Az}$ istenség az újasszír királyfeliratokban az asszír király ellenségeire lesújtó járványok megtestesítője. Nergal már a harmadik évezredben is a halálhoz szorosan kapcsolódó mezopotámiai istenség, illetve a második évezred elejétől az alvilág királyának számít. ${ }^{20} \mathrm{Az}$ alvilág uraként Nergal parancsait követik az emberek világában betegségek okozójaként tevékenykedő alvilági démonok. Nergal az újasszír korban az ország legfontosabb istenségeinek egyike, aki biztosítja az asszír király katonai gyozzelmeit, illetve „félelmet keltő ragyogásával” (akkád melammu) elpusztítja az asszír király ellenségeit. ${ }^{21}$ Mindkét istenség fö kultuszhelye a babilóniai Kutha városban található Emeslam szentély, illetve Erra és Nergal alakja az egymást átfedő funkciók miatt az első évezredre lényegében összeolvadt. Forrásainkban az istenség általában felemészti (akkád akālu) vagy leüti (akkád mahāṣu) áldozatait, illetve a járványokkal való szoros kapcsolatukat jelzi, hogy fentebb tárgyalt mūtānu šibṭu betegségeket forrásaink „Erra vagy Nergal isten csapásaként” is említik. Forrásainkban a betegségek okozói gyakran különböző démonok vagy halotti szellemek, a démonok közül elsősorban az Asakku és Namtar kapcsolható a járványos betegségekhez. ${ }^{22}$

\footnotetext{
${ }^{17}$ KAR 44 20. sor. A szöveg feldolgozásához a legújabban lásd Geller 2018.

${ }^{18}$ Erra istenhez lásd Edzard 1976-1980.

${ }^{19}$ Az Erra eposzhoz lásd Cagni 1969, Cagnin 1977, Foster 2005: 880-911, Farber 2008: 262-267 és George 2013 .

${ }^{20}$ Nergal isten alakjához lásd Weiher 1971 és Wiggermann 1999.

${ }^{21}$ Livingstone 1989: 27: 5-7.

${ }^{22}$ Asakku démonhoz lásd Bácskay 2013.
} 
Az ékírásos szöveghagyományban Asakku számos betegség okozójaként ismert (epilepszia, láz, bőrbetegség stb.), azonban alakja leggyakrabban a fentebb tárgyalt di'u betegséghez kapcsolható. A démon járványos betegségekhez való kapcsolódása vélhetően összefügg azzal, hogy Asakku alakja összekapcsolódik a tisztasági és vallási tabuk megszegésével, a démon megragadja, megköti, megérinti vagy megüti az áldozatait. ${ }^{23}$ Pusztító erejét demonstrálja, hogy a Lugale mítoszban Asakku a világ elpusztítására törekvő, kövekből álló hadsereg vezetője, a káosz erőinek megszemélyesítője, a világot pusztító természeti erőkben (árvíz és szélvihar) manifesztálódik. ${ }^{24}$

\section{AMULETTEK ÉS KENÖCSÖK A JÁRVÁNYOS BETEGSÉGEK ELLEN}

A betegségek és démonok támadásával szemben használt mágikus praktikák egyik jól dokumentált eljárása a sumer vagy akkád nyelvű ráolvasást, illetve esetenként ikonográfiai ábrázolást is tartalmazó agyagtáblát formázó amulettek alkalmazása. A tetején a felfüggesztésre szolgáló füllel ellátott, agyagtáblát formázó, kőből vagy agyagból készített tárgyakat a lakóházak, illetve bizonyos helyiségek falára akasztották. ${ }^{25} \mathrm{~A}$ ráolvasás szövege és az ikonográfia a tábla testére került, a tábla fülén pedig általában egy rövid varázsige és az amulett tulajdonosának neve szerepelt. E tárgycsoport egyik típusát képezik azok a szöveges amulettek, amelyek célja a fentebb tárgyalt járványos betegségek távoltartása. ${ }^{26} \mathrm{~A}$ szakirodalomban „pestis amulettnek” vagy „házi áldásnak” nevezett tárgyak egy részére az Erra eposz szövegének valamely részletét írták fel, ${ }^{27}$ másik részük pedig olyan ráolvasásokat tartalmaztak, melyek szövegében az eposz legfontosabb szereplői (Erra, Isum, a

\footnotetext{
${ }^{23}$ Wiggermann 2011: 310 és Bácskay 2013: 5.

${ }^{24}$ Van Dijk 1983: 20-27 és Bácskay 2013: 5.

${ }^{25}$ Némelyik ilyen jellegü amulett célja a rossz álmok pácienstől való távol tartása, ami arra utalhat, hogy a tárgyat talán a hálószobában helyezték el. Így például a Bulalu számára készített amuletten (KAR 282) szereplő ráolvasás szövege arra utal, hogy az amulett a páciens számára védelmet nyújt a rossz álmok ellen. A szöveg feldolgozásához lásd Maul-Strauß 2011: no. 22. Az Erra eposz releváns sora (5. tábla 57. sor) szerint az amulettet a lakóház belsejében kellett felakasztani.

${ }^{26} \mathrm{Az}$ amulettek e csoportjához lásd Reiner 1960 és Heeßel 2014.

${ }^{27}$ Jelenleg öt ilyen tárgyat ismerünk: BM 118998 (származási hely: Assur; tartalma: 3. tábla részlete Reiner 1960: 149), KAR 166 (Assur; tartalma: 5. tábla részlete), KAR 169 (származási hely: Assur; tartalom: 5. tábla szövege), Bu 91-5-9, 174 (tartalma: 5. tábla részlete), Bu 91-5-9, $186+$ 206 (tartalma: 5. tábla részlete), U 18122 (származási hely: Ur; tartalma: 5. tábla részlete).
} 
Hetek és Marduk), illetve Erra legfontosabb ellenfeleinek számító Isum és Marduk szerepel. ${ }^{28} \mathrm{~A}$ járványos betegségek (diu, šibbu, šibțu, mūtānu) e ráolvasásokban perszonifikált démoni alakként jelennek meg. ${ }^{29}$

Az Erra eposz történetének lényege, hogy a Marduk istentől a főhatalmat ideiglenesen átvevő Erra az emberek elpusztításáról dönt, a pusztítást Erra a fegyvereként funkcionáló Hetekre (Szebittik), ${ }^{30}$ valamint a minisztereként és tanácsadójaként szolgáló Isum istenre bízza. Erra a háború okaként az emberek és az állatok túlszaporodását, valamint az istenek tiszteletének elhanyagolását jelöli meg. Az országban zajló öldöklésnek Isum Errához intézet beszédei vetnek véget, melyben Isum Erra korlátlan hatalmát és pusztító erejét idézi fel. Ezt követően Erra haragja lecsillapodik, és beszédében a babiloni királyok uralma alatt álló ország gyarapodását ígéri. Az eposz szövegének mágikus amuletteken való alkalmazását az eposz befejező sorai fogalmazzák meg: „Legyen bár haragos Erra és dühöngjenek a Hetek, a járvány kardja nem közelít (ahhoz) a házhoz, amelyben ezt a táblát elhelyezték és (a ház) épségben marad." ${ }^{11}$ Az eposzszöveg szerint a mü szerzője Kabti-ilani-Marduk, Dabibi fia, akinek valamely istenség (vélhetően Isum) „az éjszaka folyamán", álom formájában juttatja el az eposz szövegét, melyet Kabti-ilani-Marduk másnap reggel jegyez le. A szöveg tehát isteni eredetü, amely alátámasztotta annak mágikus erejét és megbízhatóságát. ${ }^{32} \mathrm{Az}$ eposz nem tartalmaz utalást arra, hogy a szöveg mely részét kell az amulettre írni, azonban a legtöbb ilyen amuletten az eposz utolsó táblája vagy annak részlete szerepel. Ez azzal magyarázható, hogy ez a tábla tartalmazza Erra megnyugtatását, haragjának lecsendesítését. A mágikus erejü szöveget tartalmazó amulettet az eposz szerint a lakóházban kell elhelyezni, ennek megfelelően az ismert amulettek közül legalább egy (KAR 166) biztosan lakóházból került elő, egy további amulett (KAR 169) pedig lakóházakat tartalmazó régészeti területről származik. Az eposz teljes szövegének apotropaikus jellegére utalhat, hogy az eposz egyes tábláinak vagy az összes tábla teljes szövegét tartalma-

${ }^{28}$ Így például a „Marduk, az istenek bölcse” című ráolvasás; a releváns szövegek feldolgozásához lásd Reiner 1960: 151 és Panayotov 2018: 211-213.

${ }^{29}$ A perszonifikált betegségekhez általában lásd Wiggermann 2011: 311.

${ }^{30}$ Akkád Sebetu, a mezopotámiai csoport istenségek egyike. A hét istenből álló csoport, Nergal alá tartoznak, az Erra eposzban Anu isten adja őket Erra istennek (I tábla 28-93. sorok). A Hetekhez lásd Wiggermann 2010.

${ }^{31}$ Erra eposz V. tábla 57-58. sorok (a szerző saját fordítása).

${ }^{32}$ Kabtu-ilani-Marduk az isteni üzenetet közvetítője, amely kapcsolatba állítható az Ószövetség profetikus szöveghagyományával. A témához lásd Parpola 1997, Nissinen 2003, Frahm 2006/2008 és Stökl 2012. 
zó agyagtáblák egy részét is az amulettekhez hasonló füllel látták el. ${ }^{33} \mathrm{Az}$ amulett, illetve a tárgyra írt eposzrészlet (vagy az Erra ellenfeleit megszólító ráolvasások) segítségével az Erra isten haragját lecsillapító és ezáltal az emberiséget Erra pusztító járványaitól megvédő Isum isten mágikus védelmét lehetett biztosítani az amulettel ellátott lakóházban élők számára. Az éjszaka során fényt biztosító fáklyával összekapcsolt Isum isten Erra megbízottjaként maga is részese az Erra által okozott pusztításának, azonban az eposzban képes ura haragját lecsillapítani, és pusztító erejét lecsendesíteni, illetve az Erra által az országra bocsátott fertőzéses betegségeket és járványokat az amulett által védett házaktól távol tartani. ${ }^{34}$ Isum védelmező ereje azonban csak akkor tud érvényesülni ha a lakóházban megtalálható az eposz vagy a ráolvasás szövegét tartalmazó amulett. ${ }^{35} \mathrm{Az}$ Erra eposz szövegét tartalmazó amulettek nem említik a tulajdonos nevét, azonban a ráolvasást tartalmazó amulettek szövegében szerepel az amulett tulajdonosának neve vagy a tulajdonosra utaló, de konkrét nevet nem említő formula („PN aki PS fia”), melynek kapcsán az a lehetőség sem zárható ki, hogy a kisebb méretű amuletteket a páciens akár a nyakában is viselhette. ${ }^{36} \mathrm{~A}$ lakóház falán függő tárgyak azonban nemcsak az amulett szövegében említett konkrét személyt, hanem az amulettel ellátott ház valamennyi lakóját védték a járványos betegségektöl. Az alábbi, a felirat szövege alapján Summa-Nabú számára agyagból készített amulett (K 5984) Ninivéből került elő, a ráolvasás szövege a következő. ${ }^{37}$

${ }^{33} \mathrm{Pl}$. KAR 166 vagy KAR 169.

${ }^{34}$ Isum istenhez lásd Edzard 1976-1980, Weiershäuser 2010 és George 2015.

${ }^{35}$ Megjegyzendő, hogy Isummal szoros kapcsolatban lévő Hendursag istenhez kapcsolódó ráolvasás pecséthenger alakú amulettről is ismert, melyet a páciens a nyakában viselt (Bácskay 2018c: 104, 108 és 110-111).

${ }^{36}$ Így például a tulajdonosnevet tartalmazó K 5984 amulettet a mérete alapján viselhették nyakban, azonban az agyagból készített tárgyat nem égették ki, így törékenysége miatt az efféle használat megkérdőjelezhető.

${ }^{37}$ Az amuletthez lásd Panayotov 2018: 195 és 211-213. 


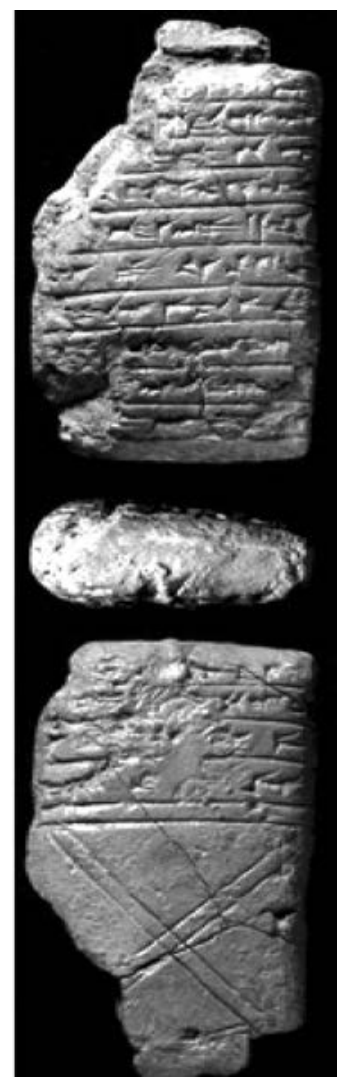

1. Ráolvasás. Marduk az istenek bölcse!

2. Erra, az istenek bajnoka!

4. Isum, az utak felügyelöje!

5. Hetek, akiknek nincs ellenfele!

6. Én vagyok Summa-Nabú, az ő (védő)istenének fia,

7. a szolga, (aki) titeket tisztel.

8. Erra (által okozott) gonosz diu, šibbu, šibțu (betegségektől), a járványtól,

9. Erra ..., a kipusztulástól

10. kíméljetek meg engem és (ezután)

11. a fekete fejüek népének

12. a ti dicsőségeteket fogom magasztalni.

Az amuletten lévő ráolvasás az Erra eposz főszereplőit szólítja meg, a fohász formájában írt szöveg az amulett tulajdonosának védelmét kéri, illetve a megszólított istenek számára fogadalmi felajánlást ígér. A ráolvasás szövege három további amulettről ismert, melyek szövegében az amulett tulajdonosa eltérő. E tárgyak kőből és agyagból egyaránt készülhettek, az anyagkülönbség vélhetően csupán az amulett ára közti különbséget jelezte. ${ }^{38}$

A járványos betegségek kapcsán különösen fontos volt az uralkodók védelme, melyet az asszír király szolgálatában álló udvari orvosok és ráolvasópapok igyekeztek biztosítani. ${ }^{39} \mathrm{Az}$ alábbi, Assur-ah-iddina asszír király szolgálatában álló egyik ráolvasópap levele a járványos betegségeket távol tartó rituálék elvégzéséről számol be az uralkodó számára. ${ }^{40}$

„A rituálékkal kapcsolatban, amelyekről a király, az én uram (korábban) írt nekünk. Kiszlev hónapban elvégeztük az »A di’u betegség, a šibțu betegség (és) a járvány

${ }^{38}$ Így például a Ninivéből származó Bu 91-5-9, 174 és Bu 91-5-9, 186 + 206 agyagból, az Assurban talált BM 118998 bazaltból készült.

${ }^{39} \mathrm{Az}$ Assur-ah-iddina és Assur-bán apli szolgálatában álló orvosokhoz és ráolvasópapokhoz lásd Radner 2011: 366-367. Magyarul lásd Bácskay 2018a: 66-69.

${ }^{40}$ A szöveg kiadásához lásd Parpola 1993: no. 296, lines 10-15, Wiggermann 1992: 91, Böck 2007: 109. Az újasszír levelekben említett betegséghez lásd Geller 2010: 76-88, magyarul lásd Bácskay 2018a: 134 . 
(mūtānu) az ember házához ne közeledjen« (című) rituálét, Tebet hónapban elvégeztük az »A betegség és a di’u betegség az ember házához ne közeledjen « (címü) rituálét."

Az elvégzett rituálé vélhetően azon ráolvasások recitálását tartalmazta, amelyre a fentebb említett „Ráolvasópap kézikönyve” című szöveg egyik sora is utal. A rituálé lefolyásáról nem maradt fenn forrás, de vélhetően a fentebb tárgyalt amulettekhez hasonló tárgyak elkészítéséről és alkalmazásáról lehet szó. A lakóházban elhelyezett amulett vélhetően folyamatosan biztosította a házban lakók védelmét, a fenti levél szövege azonban arra utalhat, hogy e betegségek ellen alkalmazott védelmet, meghatározott hónapokban végrehajtandó rituálék segítségével időről időre meg kellett újítani. ${ }^{41}$

A járványos betegségek ellen mágikus erejünek tartott kő- és fémgyöngyökből készült láncamulettekkel is védekeztek. ${ }^{42} \mathrm{Az}$ eljárás során a meghatározott számú és fajtájú gyöngyöket rögzített sorrendben füzték fel, az egyes gyöngyök közé sokszor csomókat kötöttek. Az egyes gyöngysorok önmagukban is mágikus erővel bírtak, azonban hatásukat megsokszorozta, ha több gyöngysor felhasználásával készített ún. nyakláncot alkalmaztak. E tárgyakat általában nyakban viselték, de ismerünk egyéb testrészeken (kéz, láb, csípő) viselt láncamuletteket is. Az alábbi forrás egy több kéziratból ismert amulettkőlista részlete, amely különböző istenek haragjának kiengesztelésére, valamint betegségek ellen használatos gyöngysorokat és nyakláncokat tartalmaz. ${ }^{43}$

${ }^{(12-13)}$ Férfi és női š̂u-kő, ašgigĥü-kő, haltu-kő, alabástrom, alallu-kő, „skorpió kő”, $m \bar{u}-$ șu-kő, abašmû-kő. Kilenc kő a di’u betegség (és) a járvány ellen.

${ }^{(14-15)}$ alabástrom, haltu-kő, zöld šubû-kő, „skorpió kő”, abašmû kő, férfi és női š $\hat{u}$-kő.

Kilenc kő a betegség (és) di’u betegség ellen.

Mindkét gyöngysor kilenc kőgyöngyből áll, a gyöngysorok összetétele hasonló, csupán két összetevő tér el. Bár forrásaink nem tartalmazzák az amulett használati módját, e gyöngysorokat valószínűleg a páciens a nyakában viselte. Az egyes gyöngysorokhoz felhasznált alapanyagok kiválasztásának okait forrásaink nem

${ }^{41}$ A fentebb tárgyalt amuletteken túl a lakóházak állandó rituális védelmét biztosították a lakóház különböző helyiségeiben elhelyezett védelmező szellemeket ábrázoló szobrocskák, melyek elkészítése során recitált ráolvasás szövegében a felsorolt démonok között a járványos betegségek is szerepelnek. A szöveg feldolgozásához és értelmezéséhez lásd Wiggermann 1992 és Huber 2005: 30-37.

${ }^{42}$ A láncamulettekhez lásd Schuster-Brandis 2008. Magyarul lásd Simkó 2013 és Bácskay 2018a: 198-201.

${ }^{43}$ Schuster-Brandis 2008: Text 9 iii 12-15. 
írják le, azonban megfigyelhető, hogy az egyes kövek hétköznapi és szimbolikus tulajdonságai sokszor meghatározták a kövek orvosi és mágikus felhasználását. ${ }^{44}$ E járványos betegségeket anyagokból készített kenőccsel is kezelni igyekeztek. Az alábbi késő babiloni korból származó, töredékes orvosi táblácska az alábbi receptet tartalmazza. ${ }^{45}$

(elöoldal 1-5) [...]-fa mag, [...]-fa mag, èru-fa mag, baltu-fa mag, ašăgu-fa mag, harmu$n u$-(növény) [mag]. Préseld össze (ezeket) olajban.

(hátoldal $1-2)$ Kenőcs a dỉu betegség és a járvány ellen.

A recept hat különböző növény magjából áll, amelyet olajjal kevertek össze. A kenőcs alkalmazási módját a szöveg nem tartalmazza, így vélhetően a páciens bármely testrészét, illetve a páciens egész testét bekenhették vele. A felhasznált fafélék között megtalálható baltu-fa és ašāgu-fa, amelyeket a bajelhárító és démonűző rituálékban gyakran purifikációs céllal alkalmaznak. ${ }^{46}$

A korábban tárgyalt Erra eposzban a járványos betegségek szorosan összekapcsolódnak a háborúval, illetve a hadjáratok nyomában járó pusztítás a járványok kitörésének egyik oka lehetett, így a járványos megbetegedések a hadseregre is komoly veszélyt jelenthettek. ${ }^{47} \mathrm{Az}$ újasszír kor fontos forrásának számító ún. Eponymosz krónika többször is említi a járványok (mūtānu) kitörését valamely földrajzi régió, illetve esemény kapcsán: Kr. e. 802-ben a mediterrán tengerparti régióhoz kapcsolódóan, 765-ben az Orontész folyó nyugati partján fekvő Háma királysághoz tartozó egyik település (Hatarikka) vonatkozásában, 759-ben pedig a Habúr folyó régiójában fekvő Guzána települést érintően. ${ }^{48} \mathrm{Az}$ első két esetben vélhetően a régióba vezetett asszír hadjáratok katonai eseményeivel hozható összefüggésbe a járvány kitörése, a harmadik esetben a Guzána városban kitört lázadás leverésének eseményei okozhattak járványt. ${ }^{49} \mathrm{Az}$ asszír hadseregben kitört járványos megbetegedések közül a legismertebb Szín-ahhé-eríba 701-ben vezetett Júda elleni hadjáratához köthető, melynek hatására az asszír királynak fel kellett hagynia Jeruzsálem ostromával, illetve a hadjárat folytatásával. ${ }^{50} \mathrm{Az}$ újasszír levélkorpuszhoz tartozó egyik szövegben II. Sarrukín asszír király damaszkuszi helytartója Bél-dúri arról tudósítja a királyt, hogy amikor a tartományban járvány ütötte fel

\footnotetext{
${ }^{44}$ A kérdés tárgyalásához lásd Schuster-Brandis 2008: 48. Magyarul Simkó 2013: 18-20.

${ }^{45}$ A tábla kópiájához lásd Kennedy 1969: 81 (no. 10).

${ }^{46}$ A témához lásd Bácskay-Niederreiter 2019: 182-184.

${ }^{47} \mathrm{Az}$ eposz és a háború kapcsolatához lásd George 2013.

${ }^{48} \mathrm{Az}$ asszír eponümosz krónikához lásd Glassner 2004: 164-176.

${ }^{49}$ Radner 2015: 230.

${ }^{50}$ A járványt az asszír források nem említik, az eseményről Josephus (Ant. Iud. X 1,3,5), Bérószszosz (FGrHist 680 F7a) és az Ószövetség (2 Kir. 18 és 19, valamint Izaiás 36 és 37) számol be.
} 
a fejét, az alárendeltségébe tartozó egyik katonatiszt lovat (esetleg lovakat) ölt..51 A lovak az asszír hadsereg kiemelte fontos egységeihez (a harci kocsizók és a lovasság) tartoztak, ezért megölésük a járvány időszakában vélhetően a fertőzéstől való félelemmel magyarázható. ${ }^{52} \mathrm{Az}$ asszír hadsereg járványoktól való védelmére irányuló rituálékat a középasszír és az újasszír korból egyaránt ismerünk,,$^{53}$ az alábbi, Assur-bán-apli ninivei könyvtárából származó agyagtáblákról ismert eljárás az asszír hadsereg „lovainak és lovasainak” védelmét biztosította. ${ }^{54}$

${ }^{(1-2)}$ Azért hogy a diu, šibțu (betegségek), a járvány a lovakhoz és a király hadsereghez ne közeledjen, végezd el annak namburbi rituáléját a következőképpen.

${ }^{(3-20)} \mathrm{A}$ kedvező nap estéjén állíts négy nádból (készült) oltárt: a város istenének, a város istennőjének, a város Sédu védőszellemének, a város Lamassu védőszellemének. Halmozz (az oltárra) mersu-süteményt, mézet, vajat, datolyát, sasqû-lisztet, ${ }^{55}$ „édes kenyeret”. Állíts (az áldozati asztalra) „elsőrangú sört”, bort, tejet és búzasört (tartalmazó edényeket). Szórj az áldozati felszerelés elé az összes gabonafajtából. Tölts meg a szent vizet (tartalmazó) edényből (származó) vízzel kilenc $k u k k u b u$-edényt és állítsd (az edényeket az oltárra). Dobj ezüstöt, aranyat, rezet, ólmot, vasast, karneolt, muššaru-követ és [...]-követ (minden) kukkubu-edényekbe. Önts olajat, „szürt olajat”, „jó olajat”, vajat (az edényekbe). Gyújts ašā$g u$-fa(szén) füstölőt. Áldozz négy bárányt, ajánld fel (az isteneknek) a lapockát, a belsőségeket (és) a sült húst. Biztosíts (az isteneknek) kacsát, ušummu-egeret (és) egyéb fött ételt. Áldozz „elsőrangú sört”, mihhu-sört, bort, tejet és búzasört. Tölts kilenc lahannu-edénybe „elsőrangú sört”, bort, tejet, búzasört, hím birka vérét, fiatal nőstény gida vérét, kacsa vérét, ušummu-egér vérét és „szürt olajat”. Helyezd (az edényeket) [az áldozati asztalra]. Készíts össze tűzifát, halmozz hozzá èru-fát (és) ašăgu-fát, köss rá (a farakásra) egy fiatal gidát. Halmozz fel aromatikus növényeket, sasqû-lisztet, mézet (és) olajat. Áldozz „elsőrangú sört” és bort a tűzifarakás jobb és bal oldalán. Húzz (az oltár köré) függönyt..$^{56} \mathrm{Helyezz}$ (az oltárra?) gabonahalmo-

${ }^{51}$ Parpola 1987: no. 171 és Luukko 2012: no. 171 (ugyanazon levél két kiadása). A lov(ak) leölésének másik lehetséges magyarázata a tartományt sújtó éhínség lehetett (a lovak húsa vagy a lovak számára takarmányként biztosított gabona tápláléként szolgálhatott).

${ }^{52}$ Az asszír lovassághoz magyarul lásd Dezső 2006.

${ }^{53}$ A témához lásd Wiggerman 1992: 95; Huber 2005: 24-30, Strauß 2009: 645; Maul 2007: 52-55 és Maul 2013: 16-37.

${ }^{54}$ A British Museumban őrzött 82-3-23, 1 múzeumi jelzetű ékírásos tábla kiadásához lásd Caplice 1970: 118-123 és III-IV. táblák. A tábla az újasszír korban összeállított ártó ómenek elhárítását célzó namburbi rituálék csoportjához tartozik (Maul 1994: 220).

${ }^{55}$ Finomra őrölt liszt.

${ }^{56} \mathrm{Az}$ oltár, illetve a szakrális térség profán tértől való szétválasztására a szövegekben általában lisztkört (zišurrû) használnak. 
kat, biztosíts vizet. Feszítsd ki a bronz lilissu-dobot, énekelj sirató dalokat az egyes isteneknek.

${ }^{(20-27)}$ Ezután állíts nádból (készült) oltárt Lugalgirra, Meslamtaea, Ninkilim és [...] istennek. Áldozz négy bárányt. [Készíts össze] tűzifát [...] Feszítsd ki a bronz lilissu dobot. Ültesd a királyt nádból (készült) székre. (A király) viseljen koronát. Fogd meg a (király) paršìqu-szövetbe (tekerd) kezeit (és) énekeld a siratókat. Ragadd meg (a király) kezeit, majd (a király) emelje fel (a kezeit), és álljon az áldozati felszerelés elé. Recitáltasd (a királlyal) „Az úr, a hatalmas az istenek között” (című ráolvasást). ${ }^{(28-42)}$ Ezután készíts áldozati felszerelést a Heteknek és Bélet-ili istennőnek. Halmozz (az oltárra) mersu-süteményt, mézet, vajat, datolyát (és) sasqû-lisztet. Állíts (az áldozati asztalra) „elsőrangú sört”, bort, búzasört (és) tejet (tartalmazó) adagurru-edényt. Valamennyi (ilyen) edényt helyezd el az áldozati felszerelés közelében. Halmozz (az oltárra) minden gabonaféléből. Végezz tisztító rituálét búzasörrel az (áldozati felszerelés) oldalánál. Kend be olajjal (és) „cédrus vérével”. Halmozz fel mindenféle gabonamagot, helyezd Bélet-ili áldozati felszerelése elé. Áldozz három bárányt a Heteknek, áldozz egy fiatal gidát Bélet-ili istennőnek. Ajánld fel (az isteneknek) a lapockát, a belsőségeket (és) a sült húst. Áldozz „elsőrangú sört”, bort, tejet (és) búzasört. Készíts össze tüzifát, köss rá egy fiatal gidát (és) gyújts meg a tüzet. Biztosíts vizet (a rituáléhoz). Feszítsd ki a bronz lilissu-dobot, [énekelj] sirató dalokat Bélet-ili istennőnek. [...] a király leborul (az istennő előtt?) és egyesen a palotájába megy. [...] elhagyod (a rituálé helyszínét).

(43-61) [...] tarmuš-növény, imhur-lïm-növény, imhurur-ëšra-növény, [kibrïtu-kén], rut'ìtu-kén, magnetit, šu-kö, pallišu-csiszolókő, [...]-kö, [lazúrkö], kasû-karneol, agargarìtu-kén, pappāsìtu-ásvány, szárított folyami aszfalt, por Marduk isten templomának kapujából, por Gula istennő templomának kapujából, por a Hetek templomának kapujából, az áldozati állat szőre, az áldozati állat pofájának (szőre), forró aszfalt, „cédrus vére”, „jó olaj”, méz, vaj. Főzd meg (ezeket), tegyél (hozzá) luludanìtu-követ, abašmû-követ, istenek templomának kapujából származó vörös színü port, arzallu-követ, turullu-követ (és) elkulla-növényt. Nyomd szét szürt olajban, tegyél hozzá gipszet, keverd össze búzasörrel, hígítsd fel szent vízben. Tartsd bent a tábor lovait (és) kend be többször a tábort. Fiatal gida vérét, ěšsebu-madár vérét, fekete bika vérét (és) fehér ló vérét keverd össze olajjal. A maradék forró aszfalt és gipsz, búzaliszt, inninnu-gabona lisztje, ašāgu-fa gyökere, èru-fa magja, azallu-növény, dadānu-fa magja, šuršurru-növény, amdudu-növény, „rókabor" növény, anzahhu-ásvány, mūṣu-kö, sābu-kö, pallišu-csiszolókö. Ezt a 15 (anyagot) keverd össze, [tedd?] bőrzsákba amelyet helyezz Bélet-ili istennő elé (majd) tedd a lovak nyakába. Ugyanezzel a kenőccsel kend be (a tábor) valamennyi kapujának küszöbét. 
A fentebb idézett, több eljárásból álló rituálé során étel- és italáldozatot mutattak be különböző istenek számára. Az áldozati felajánlások célja a rituálé kapcsán fontos istenségek megszólítása, illetve segítségül hívása. A megszólított istenségek között védőszellemek (Sédu és Lamassu), démonűző isteni alakok (Lugalgirra és Meslamtaea), valamint gyógyító istennő (Bélet-ili) is található. Az áldozati felajánlás során a különböző ételeket és italokat helyeztek az istenség előtt felállított áldozati asztalra. A rituálé része állatok feláldozása is, melynek bizonyos részeit az istenségek számra áldozati ételként szolgálják fel. A rituálé során sumer nyelvű siratókat adtak elő dobkísérettel. Az áldozati felajánlást kenőcsök elkészítése követte, amelyet a tábor kapujának küszöbére kentek, valamint a lovak nyakába akasztva amulettként alkalmaztak. ${ }^{57}$

A fentebb bemutatott rituálék mellett a tárgyalt járványos betegségek az 1. évezredi standard mágikus-orvosi ráolvasássorozatok (Utukku lemnūtu, Asakku marșūtu, Muruṣ qaqqadi, Mǔ̌šu) szövegeiben is szerepelnek, azonban ezekben a ráolvasássorozatokban a tárgyalt terminusok csupán az ártó démonokat és a démonokhoz szorosan kapcsolt betegségeket a listaszerűen felsoroló ún. „betegségkatalógus" részeként jelennek meg. ${ }^{58}$

\section{IRODALOM}

AвUsch, T.: „The Socio-religious Framework of the Babylonian Witchcraft Ceremony Maqlû: Some Observations on the Introductory Section of the Text, Part II", in Z. Zevit - S. Gitin - M. Sokoloff (eds.): Solving Riddles and Untying Knots: Biblical, Epigraphic, and Semitic Studies in Honor of Jonas C. Greenfield, Winona Lake, Eisenbrauns, 1995, 467-494.

Aвusch, T.: Mesopotamian Witchcraft: Towards a History and Understanding of Babylonian Witchcraft Beliefs and Literature, Groningen-Leiden, Brill, 2002.

AtTINGer, P.: „La médecine mésopotamienne”, JMC 11-12 (2008), 1-96.

Bácskay A.: „Papi tisztasági rituálék a Kr. e. 1. évezredi Mezopotámiában”, http://vallastortenet.hu/ index.php/Axis/issue/archive

BÁcskay A.: Orvoslás az ókori Mezopotámiában A mezopotámiai gyógyitó rítusok elmélete és gyakorlata, Pécs-Budapest, L'Harmattan Kiadó, 2018a.

BÁcskay, A.: Therapeutic Prescriptions against Fever in Ancient Mesopotamia, Münster, Ugarit Verlag, 2018b.

${ }^{57}$ Mindkét eljárás jól ismert mágikus-orvosi szövegekből. A bőrzsákba helyezett vagy gyapjúszövetbe tekert amulettek (profülaktériák) általában egyéb kezelések (pl. kenőcs, borogatás) kiegészítő eljárásaként szerepelnek. A profülaktériákhoz lásd Farber 1973, Weiher 1983: 109-121, Maul 1994: 107-113. Magyarul lásd Bácskay 2018a: 202-204. A lakóházak küszöbének mágikus védelme arra irányul, hogy az ártó erőt, betegségeket hordozó démonok ne tudjanak behatolni a házba. Az eljáráshoz lásd Maul 1994: 99.

${ }^{58}$ A felsorolt mágikus-orvosi ráolvasássorozatokban szereplő járvánnyal összefüggő kifejezések tárgyalásához lásd Huber 2005: 38-46 és Böck 2018: 250-254. 
BÁcskay, A.: „The 34th Extract of the UGU Series from Babylon: An Edition of the Tablet BM 35512”, in S. V. Panayotov - L. Vacin (eds.): Mesopotamian Medicine and Magic. Studies in Honor of Markham J. Geller. Leiden-Boston, Brill, 2018c, 93-115.

BÁCSKAY A.: „A szakrális vétség és a személyes istenség haragja Mezopotámiában”, in Hubai P. (szerk.): Bün-vallás és kegyelem: Elöadások a vallástudomány és a theológia vonzásköréböl. Budapest, Wesely János Lelkészképző Főiskola, 2014, 32-45.

Bácskay, A.: „Asakkû: Demons and Illness in Ancient Mesopotamia”, in H. R. Jacobus - A. K. de Hemmer Gudme - Ph. Guillaume (eds.): Studies on Magic and Divination in the Biblical World. Piscataway, Gorgias Press, 2013, 1-8.

BÁcskay A. - Simкó K.: „Bőrbetegségek az ókori Mezopotámiában. Diagnózis és terápia”, Kaleidoscope 2017/15 (2017), 1-18.

BÁcskay A. - Niederreite Z.: „Bölcs tudósok, a nagy istenek titkának őrzői. A tudósok és a tudományos szövegek szerepe a mezopotámiai mágiában”, in Nagy Á. (szerk.): Az Olympos mellett. Mágikus hagyományok az ókori Mediterraneumban I., Budapest, Gondolat, 2013, 183-218.

Böck, B.: Das Handbuch Muššu’u "Einreibung”. Eine Serie sumerischer und akkadischer Beschwörungen aus dem 1. Jt. vor Chr., Madrid, Consejo Superior de Investigaciones Científicas, 2007.

Böск, B.: The Healing Goddess Gula: Towards an Understanding of Ancient Babylonian Medicine, Leiden, Brill, 2014.

Böск, B.: „Reusing Incantations and Making New from Old: On the Formation and Therapeutic Objective of the Muššủ (»Embrocation«)" Compendium in T. Abusch - A. K. Guinan - N. P. Heeßel - F. A. M. Wiggermann (eds.): Sources of Evil Studies in Mesopotamian Exorcistic Lore, Leiden-Boston, Brill, 2018, 237-26o.

Cagni, L.: L’epopea di Erra, Rome, Pontificium Institutum Biblicum, 1969.

CAGNI, L.: The Poem of Erra, Malibu, Undena Publications, 1977.

Caplice, R.: „Caplice Namburbi Texts in the British Museum IV”, Orientalia NS 39/1 (1970), 111-151.

Dezső T.: „Az asszír lovasság története”, Ókor 5/3-4 (2006), 62-70.

Durand, J. M.: Archives Epistolaires de Mari, Editions Recherche sur les Civilisations, Paris, 1988.

Durand, J. M.: Les documents épistolaires du palais de Mari, Paris, Les Éditions du Cerf, 2000.

EDZARD, D. O.: „Irra”, RLA 5 (1976-1980), 166-170.

FARBER, W.: „ina kuš.dù.dù(.bi) = ina maški tašappi”, ZA 63 (1973), 59-68.

FARBER, W.: „How to marry a disease: epidemics, contagion, and a magic ritual against the "hand of the ghost"', in H. F. J. Horstmanshoff - M. Stol (eds.): Magic and Rationality in Ancient Near Eastern and Graeco-Roman Medicine, Leiden-Boston, Brill, 2004, 117-131.

FARBER, W.: „Die einleitende Episode des Erra-Epos”, Altorientalische Forschungen 2 (2008), 262-267.

Foster, B.: Before the Muses. An Anthology of Akkadian Literature, Bethesda, CDL Press, 2005.

Frahm, E.: „Prophetie”, RLA 11 (2006/2008), 7-11.

Frankena, R.: Briefe aus dem British Museum, Leiden, Brill, 1966.

Geller, M. J.: „, The Exorcist's Manual (KAR 44)”, in U. Steinert (ed.): Assyrian and Babylonian Scholarly Text Catalogues: Medicine, Magic and Divination, Berlin, De Gruyter, 2018, 292-312.

George, A. R.: „The poem of Erra and Ishum: A Babylonian poet's view of war”, in H. Kennedy (ed.): Warfare and Poetry in the Middle East, London - New York, I. B. Tauris, 2013, 39-71.

George, A. R.: „The Gods Išum and Hुendursanga: Night Watchmen and Street-lighting in Babylonia", Journal of Near Eastern Studies 74 (2015), 1-8.

GLASSner, J.: Mesopotamian Chronicles, Society of Biblical Literature, 2004.

Guichard, M. - Marti, L.: „Purity in Ancient Mesopotamia: The Paleo-Babylonian and Neo-Assyrian Periods", in Ch. Frevel - Ch. Nihan (eds.): Purity and the Forming of Religious Traditions in the Ancient Mediterranean World and Ancient Judaism, Leiden-Boston, Brill, 2013, 47-113. 
HeEssel, N. P.: „Amulette und 'Amulettform': Zum Zusammenhang von Form, Funktion und Text von Amuletten im Alten Mesopotamien”, in J. F. Quack - D. C. Luft (Hrsg.): Erscheinungsformen und Handhabungen Heiliger Schriften, Berlin-München-Boston, De Gruyter, 2014, 53-77.

Huber, I.: Rituale zur Seuchen- und Schadensabwehr im Vorderen Orient und Griechenland: Formen kollektiver Krisenbewältigung in der Antike, Stuttgart, Steiner-Verlag, 2005

KenNedy, D.: „Realia”, Revue d'Assyriologie et d'archéologie orientale 63/1 (1969), 79-82.

Kinner-WiLson, J. - Finkel, I.: „On bušānu and di’u, or why Nabonidus went Tema”, JMC 9 (2007), $16-22$.

KLENGel, H.: „Epidemien im spätbronzezeitlichen Syrien-Palästina”, in Y. Avishur - R. Deutsch Michael: Historical, Epigraphical and Biblical Studies in Honor of Prof. Michael Heltzer, Tel Aviv-Jaffa, Archaeological Center Publication, 1999, 187-193.

Livingstone, A.: Court Poetry and Literary Miscellanea, Helsinki, Helsinki University Press, 1989.

Luukко, M.: The Correspondence of Tiglath-Pileser III and Sargon II from Calah/Nimrud, Helsinki, Helsinki University Press, 2012.

MAUL, S. M.: Zukunftsbewältigung: Eine Untersuchung altorientalischen Denkens anhand der babylonisch-assyrischen Löserituale (Namburbi), Mainz, Philipp von Zabern, 1994.

Maul, S. M.: „Militärpferde im Alten Orient” in A. Wieczorek - M. Tellenbach (Hrsg.): Pferdestärken. Das Pferd bewegt die Menschheit, Begleitband zur Sonderausstellung "Pferdestärken - Das Pferd bewegt die Menschheit", Darmstadt-Mannheim, Reiss-Engelhorn-Museen, 2007, 51-56.

Maul, S. M. - Strauss, R.: Ritualbeschreibungen und Gebete, I., Wiesbaden, Harrassowitz, 2011

Maul, S. M.: „Ein altorientalischer Pferdesegen: Seuchenprophylaxe in der assyrischen Armee”, Zeitschrift für Assyriologie 103 (2013), 16-37.

Nissinen, M.: Prophets and Prophecy in the Ancient Near East, Atlanta, Society of Biblical Literature, 2003.

Panayotov, S. V.: „Magico-medical Plants and Incantations on Assyrian House Amulets. In: Sources of Evil Studies in Mesopotamian Exorcistic Lore", in T. Abusch - A. K. Guinan - N.P. Heeßel - F. A. M. Wiggermann (eds.): Sources of Evil Studies in Mesopotamian Exorcistic Lore, Leiden-Boston, Brill, 2018, 192-222.

Parpola, S.: The Correspondence of Sargon II, Part I: Letters from Assyria and the West, Helsinki, Helsinki University Press, 1987.

Parpola, S.: Letters from Assyrian and Babylonian Scholars, Helsinki University Press, Helsinki, 1993. Parpola, S.: Assyrian Prophecies, Helsinki University Press, Helsinki, 1997.

RADNER, K.: „Royal decision-making: kings, magnates, and scholars”, in K. Radner - E. Robson (eds): The Oxford Handbook of Cuneiform Culture, Oxford University Press, Oxford, 2011, 358-379.

RADNER, K.: „The Assyrian king and his scholars: the Syro-Anatolian and the Egyptian Schools”, Studia Orientalia 106 (2015), 221-238.

Reiner, E.: „Plague Amulets and House Blessings”, Journal of Near Eastern Studies 19 (1960), 148-155.

ReIner, E.: Šurpu: A Collection of Sumerian and Akkadian Incantations, Biblio Verlag, Osnabrück, 1970.

Schuster-Brandis, A.: Die Steine als Schutz, und Heilmitttel, Münster, Ugarit Verlag, 2008.

Siмкó, K.: „The abrasive stone in Assyrian and Babylonian Medicine”, Le Journal des Médecines Cunéiformes 22 (2013), 24-60.

StoL, M.: „Fevers in Babylonia”, in I. L. Finkel - M. J. Geller (eds.): Disease in Babylonia, Leiden, Brill, 2007, 1-39.

STÖKL, J.: Prophecy in the Ancient Near East, Leiden, Brill, 2012.

Strauss, R.: „Review of I. Huber, Rituale der Seuchen- und Schadensabwehr im Vorderen Orient und Griechenland", Orientalistische Literaturzeitung 104 (2009), 643-650. 
ToORN, K. vAN DER: Sin and Sanction in Israel and Mesopotamia, Assen, 1985.

VAN DijK, J. J.: The Ninurta Myth Lugal-e, Ledien, Brill, 1983.

WeIershäUSER, F.: „Weiser Išum, der du den Göttern vorangehst”, in D. Shehata - F. Weiershäuser - K. Zand (Hrsg.): Von Göttern und Menschen. Beiträge zu Literatur und Geschichte des Alten Orients. Festschrift für Brigitte Groneberg, Leiden, Brill, 2010, 351-376.

Weiner, E.: Der babylonische Gott Nergal, Neukirchener Verlag, Neukirchen-Vluyn, 1971.

WeIHer, E.: Spätbabylonische Texte aus Uruk, Teil II, Berlin, Gebr. Mann, 1983.

Wiggermann, F. A. M.: Mesopotamian Protective Spirits. The Ritual Texts, Groningen, Styx, 1992.

Wiggermann, F. A. M.: „Nergal. A. Philologisch”, RLA 9 (1999), 215-223.

Wiggermann, F. A. M.: „Siebengötter”, RLA 12 (2010), 459-466.

Wiggermann, F. A. M.: „The Mesopotamian Pandemonium: A Provisional Census”, Studi e Materiali di Storia delle Religioni 77/2 (2011), 298-322. 